\title{
Biodiversity, richness and spatial distribution of extant Pteridophytes in Kudremukh National Park, Western Ghats, India
}

\author{
Shaiesh Morajkar ${ }^{1,2}$ \& Smitha Hegde ${ }^{3^{*}}$ \\ ${ }^{1}$ Department of Postgraduate Studies and Research in Biotechnology, St Aloysius College (Autonomous), Mangalore, Karnataka 575003 , India \\ ${ }^{2}$ Goa State Wetland Authority, O/o Goa State Biodiversity Board, DSTE complex, Saligao, Bardez, Goa 403 511, India \\ ${ }^{3}$ Nitte (Deemed to be University), Nitte University Centre for Science and Research (NUCSER) Mangalore, Karnataka 575 018, India \\ *Email: smitha.hegde@nitte.edu.in
}

\section{ARTICLE HISTORY}

Received: 21 December 2020

Accepted: 02 May 2021

Available online: 21 August 2021

\section{KEYWORDS}

Ferns

Indexing methods

Qualitative

Quantitative

QGIS

\section{ABSTRACT}

Pteridophyte richness and diversity in Kudremukh National Park (KNP) was assessed using qualitative and quantitative diversity indexing methods, along with the geographic spatial distribution of the extant pteridophyte flora. The field research design employed a stratified random sampling method and was conducted in two phases. Phase 1 included the survey, identification and distribution of the pteridophyte flora and Phase 2 was to study the diversity of the extant pteridophytes throughout the KNP using seven transects. The region exhibited rich and highly diverse (Shannon-Wiener Diversity Index of 3.38), non-homogenous (compared to normal Raunkiaer's frequency curve) stand of 46 different unevenly (evenness index 0.64) distributed pteridophyte flora. The study region was dominated by two unambiguous pteridophyte species of weedy nature (Pteridium aquilinum and Dicranopteris linearis), with a high Simpson's dominance index of 0.96. The study reports eight endemic, two rare, five at risk and seven vulnerable and near-threatened IUCN listed pteridophyte species in the study region. The quantitative diversity indices i.e. frequency, density, abundance, relative abundance and important value index of each extant pteridophyte is calculated. The study also noted that some endemic species such as Osmunda huegeliana and Cyathea nilgirensis present in KNP needed immediate conservation efforts. This study gives an extensive report on the extant pteridophyte flora of KNP and will help future taxonomic surveys and research, as well as conservation and sustenance measures.

\section{Introduction}

Pteridophytes or ferns and fern allies are the most primitive group of vascular plants as they emerged shortly after the evolution of land plants and played an essential role in establishing the early land flora (1) and hence probably resulting in the evolution and characterization of the present-day pteridophytes. However, with the upheavals in the evolutionary period most of this arboreal vegetation, including many tree ferns, has perished. The extant pteridophytes form a critical component of the forest ecosystem and occupy various niches on land, marshes, swamps and water bodies (2). They thrive in moist tropical and temperate forests whilst, they also occur in diverse eco-geographical regions where the conditions are not favourable for growth $(3,4)$.

The Western Ghats of India covers only 5\% of India's total geographical area with humid tropical forest on rugged mountains which constitute regions of high diversity and endemism (4) containing more than $27 \%$ of the country's total plant species. The altitudinal gradient coupled with differential onset and withdrawal of southwest and northeast monsoon results in a disparity of dry seasons, which in turn influence the formation of unique ecological mosaics representing a high degree of biological diversity (5) and endemism (6). The Western Ghats harbour 349 pteridophytic species out of 1100-1200 species are found in India (7). Many researchers have assessed the diversity of pteridophytes in the Western Ghats at varying geographic scales from the entire region (8 10) to local scale (11-15). Such expeditions are very crucial for devising conservation and sustenance strategies for vulnerable and threatened species. Kudremukh National Park (KNP) $\left(13^{\circ} 1^{\prime}\right.$ to $13^{\circ} 29^{\prime} \mathrm{N}$ latitude and $75^{\circ} 0^{\prime}$ to $75^{\circ} 30^{\prime} \mathrm{E}$ longitude) is one such area in the Western Ghats in the state of Karnataka. It covers an area of $600.34 \mathrm{~km}^{2}$ which includes three forests viz., Tungabhadra, South Bhadra and Narasimha Parvatha and two reserve forests viz., Naravi and Andar, within the state of Karnataka. KNP

(c) Morajkar \& Hegde (2021). This is an open-access article distributed under the terms of the Creative Commons Attribution License, which permits unrestricted use, distribution and reproduction in any medium, provided the original author and source are credited (https://creativecommons.org/licenses/by/4.0/). 
has been recognized as a world heritage cluster and eco-sensitive area (16). The presence of many perennial streams, waterfalls and other moist habitats in KNP support rich growth of pteridophytes. A preliminary examination of the pteridophytes in KNP (17) enlisted the pteridophytes present in the region. No other significant study or data enumerating and highlighting the status of pteridophyte flora in KNP has been conducted. Thus, meagre conservation and sustenance measures are reported for pteridophytes in the region.

Most biodiversity studies are index-based assessments that use endemism and species richness indices as surrogates for the conservation value of a region $(18,19)$ and form an essential part of conservation programmes (20). Effective management plans and actions can only be achieved with valuable spatial information (21). Broad-scale patterns of species richness and endemism are often documented however required detailed distribution data of taxa are not available for the vast majority of pteridophyte groups (22). Most studies in the Western Ghats are constrained by reliance on limited and patchily distributed point data from field surveys or biological collections such as herbaria (23). Hence, the current study was undertaken to assess and document diversity, distribution and endemism of extant pteridophytes in KNP. This study will help identify the status of pteridophytes in this region, which will aid in planning future sustenance strategies and focus implementation of conservation of pteridophytes of KNP if and when required. The approach demonstrated in the present paper is a unique attempt which takes advantage of indexbased diversity assessment in combination with a sizeable geo-referenced dataset to study pteridophyte diversity and distribution in the KNP region.

\section{Materials and Methods}

\section{Details of the study site and data collection}

The study region included the entire KNP covering approximately $600.34 \mathrm{~km}^{2}$ of dense tropical forest and grasslands. The field research design employed in the current study used a stratified random sampling method and was conducted in two phases. Phase 1 included the survey, identification and distribution of the pteridophyte flora, and Phase 2 examined index-based diversity of the extant pteridophytes in KNP using transects. In Phase 1, three surveys (extending up to 14 days each) were conducted, one in each of the three major mountain ranges of KNP. Twenty-three sampling sites (Fig. 1) were studied as reference points for conducting the field survey. Details of the sampling sites are given in Supplementary Table 1 . The forest department field stations were used as the starting point of every range for sampling. Using a transect-walk method the sample data was collected at every $1 \mathrm{~km}$ interval of tracking. Different growth forms of pteridophytes were recorded i.e., terrestrial, epiphytic and lithophytic. Diagnostic features of all the specimens were studied and referred to available literature (2426) for accurate taxonomic identification of the collected pteridophyte species. Pteridophyte samples were preferentially plucked with their rhizomes/roots intact with the help of a digger and removal of other underground portion. Samples were preserved as herbarium (27) and stored at St Aloysius College, Mangalore. The location and geographic distribution of the collected pteridophyte samples were recorded using a handheld GPS (Garmin GPS etrex20). IUCN threat status of all the extant pteridophytes was referred from other literature (28, 29). Growth habit, along with the range wise distribution of every pteridophyte was observed in all the major ranges of the KNP.

After completion of Phase 1, four surveys were conducted in Phase 2. A total of 7 transects measuring $50 \mathrm{mx} 2 \mathrm{~km}$ were laid (shown in Fig. 1 and the details are given in supplementary Table 1). The representative points were selected using a stratified method, based on the data available from Phase 1 survey. Transects was laid in sites having the presence of pteridophytes in all three major ranges of KNP mentioned. The data of all pteridophyte species incident in the 7 transects were collected and analyzed through statistical methods $(30,31)$.

\section{Distribution analysis}

The GPS data of all the extant pteridophyte species collected from Phase 1 survey was used to map the spatial distribution of number of fern species. Subsequently a graphical representation of the pteridophyte species assemblage using QGIS Essen (2.14.1) was obtained. The vector data in a delimited text layer (CSV) was used to create a raster file. The number of different fern species was used as the attribute and Inverse Distance Weighing (IDW) method was used for interpolation of a discrete single band pseudo-colour raster file. Finally the obtained raster file was clipped onto the KNP shape file to obtain a bit map of species distribution.

\section{Species diversity analysis}

Based on the data of occurrence of pteridophyte species in transects from Phase 2, important qualitative diversity indices (32-34) i.e.

Simpson's dominance index $\left(\mathrm{D}=1 / \sum_{i=1}^{s} p_{i}^{2}\right)$,

Shannon-Wiener diversity index $\left(\mathrm{H}=\sum_{i=1}^{s} p_{i} \operatorname{In} p_{i}\right)$

and species evenness index $(E=H / \ln (s))$ were calculated.

Wherein $\mathrm{p}$ is the proportion $(\mathrm{n} / \mathrm{N})$ of individuals of one particular species found (n) divided by the total number of individuals found $(\mathrm{N}), \mathrm{ln}$ is the natural log, $\Sigma$ is the sum of the calculations and $\mathrm{s}$ is the number of species. The analysis were performed by using SPSS (v21) and PAST (v3.17) statistical software.

Quantitative analysis of diversity data was carried out using MS Excel 2010. Density (D), Frequency (F), Abundance (A) and Relative abundance (RA) i.e. the study of the numerical strength of a species with the total number of individuals of all the species were analyzed using the formulae's (a), (b), (c) and (d) respectively. 


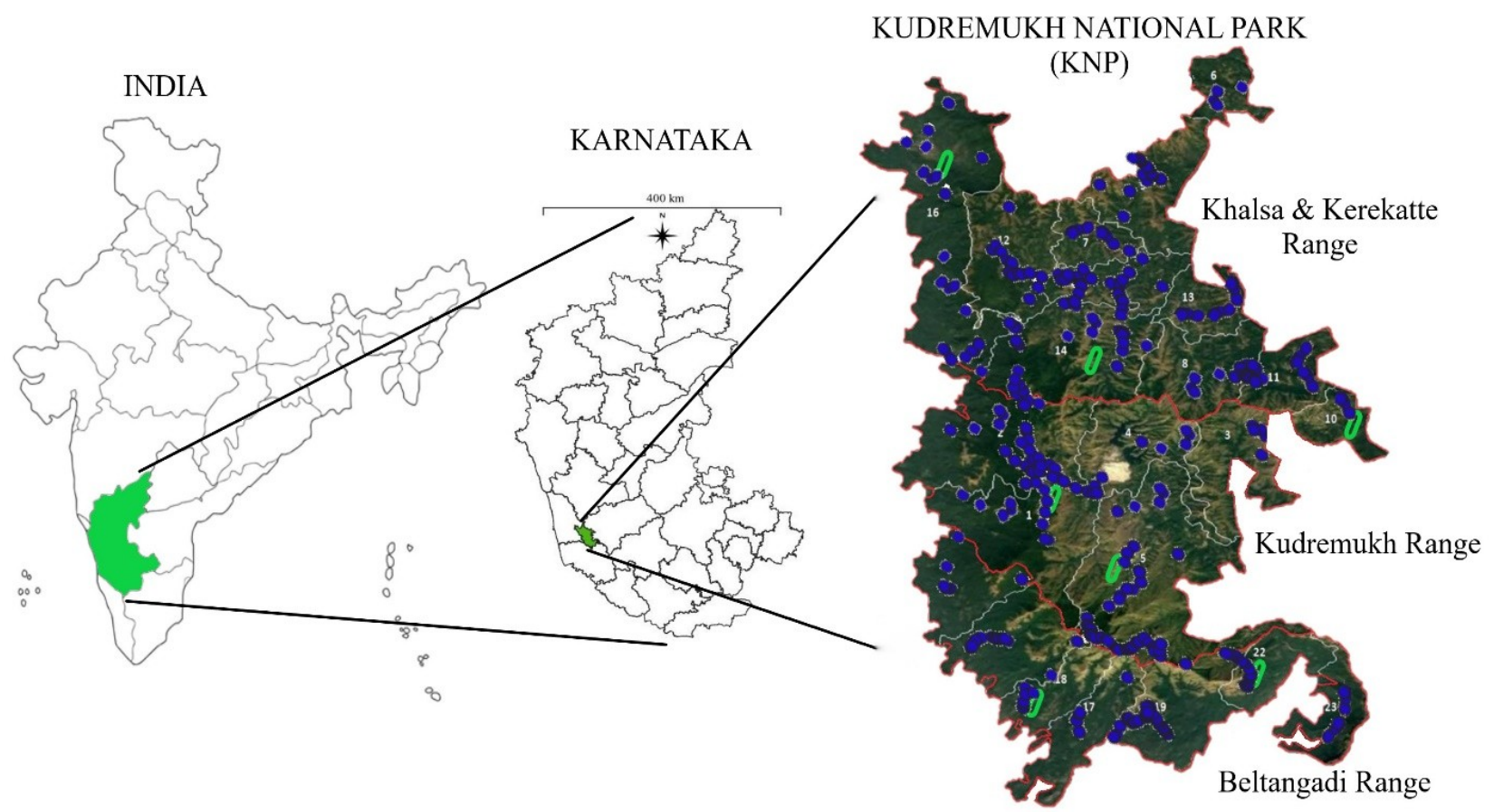

๑๑ Transect walk at Phase 10 Transects at Phase 2 survey

Fig. 1. Depicts the location of Kudremukh National Park (KNP) illustrating the three major ranges and the sampling sites of Phase 1 and Phase 2 survey in Google Earth Pro 7.3.3.7786 (64-bit); (Note the number codes of reference sampling sites illustrated in the Figure are enlisted in Supplementary Table 1).

Density $(D)=\frac{\text { Total number of individual species }}{\text { Total number of transects studied }} \times 100$

(a)

Frequency $(F)=\frac{\text { Number of transects in } \text { which speciesstudied }}{\text { Total number of transects studied }}$

(b)

Abundance $(A)=\frac{\text { Total } \text { number of individual } \text { speciesin all transects }}{\text { Total number transects in which speciesoccurred }} \times 100$

(c)

Relative Abundance $(R A)=\frac{\text { Abundance of individual species }}{\text { Total abundance of all species }} \times 100$ (d)

Importance Value Index (IVI) i.e. the overall importance of each species in the community structure (31) was calculated using equation (e)

$I V I=$ relative frequency + relative density + relative abundance (e)

The ratio of abundance to percentage frequency provided information about the nature of the distribution of the individual pteridophyte species. Values <0.025, $0.025-0.05$ and $>0.05$, indicates regular, random and contagious distributions, respectively (35). The frequency data of the pteridophyte community was then further classified and grouped into Raunkiaer's law of frequency (36) classes A, B, C, D and E and compared against the normal frequency curve to understand the homogeneity of a stand of extant pteridophyte flora in the KNP.

\section{Results}

\section{Extant pteridophytes and their distribution in KNP}

A total of 46 pteridophyte species were collected and identified (Table 1), which belonged to nineteen families: Marattiaceae, Gleicheniaceae, Pteridaceae, Dennstaedtiaceae, Lycopodiaceae, Osmundaceae, Tectariaceae, Dryopteridaceae, Blechnaceae, Cyatheaceae, Thelypteridaceae, Lygodiaceae, Lindsaeceae, Aspleniaceae, Davalliaceae, Selaginellaceae, Woodsiaceae, Polypodiaceae and Lomariopsidaceae, spreading across eight different orders. The dominant pteridophyte families were Pteridaceae with eleven species followed by Thelypteridaceae and Polypodiaceae with four species each.

Among the pteridophytes found in the KNP (Table 1), 31 species are commonly found in the Western Ghats. The most common and widely distributed pteridophyte species in the study area are Pteridium aquilinum (L.) Kuhn, Dicranopteris linearis (Born. f.) Underw, Blechnum orientale L., Adiantum philippense L., Christella parasitica (L.) H. Lev., Christella dentata (Forssk.) Brownsey \& Jermy, Pteris quadiaurita Retz., Pteris biaurita L. and Pteris confusa T.G. Walker. The area is also notable for rare and endemic species (Table 1) such as Selaginella tenera (Hook. \& Grev.) Spring, Osmunda huegeliana C. Presl., $P$. quadiaurita Retz., Bolbitis subcrenatoides FraserJenk., Bolbitis semicordata (Baker) Ching., Cyathea nilgirensis Holttum., C. paracitica (L.) H. Lev. 
Table 1. Pteridophyte habitat, threat status, growth habit and distribution status throughout KNP.

\begin{tabular}{|c|c|c|c|c|c|c|}
\hline \multirow{2}{*}{ Pteridophyte species } & \multirow{2}{*}{ Habitat } & \multirow{2}{*}{$\begin{array}{l}\text { Threat Status } \\
\text { (IUCN) }\end{array}$} & \multirow{2}{*}{ growth habit } & \multicolumn{3}{|c|}{ Range Distribution } \\
\hline & & & & $2 \mathrm{~K}$ & $\mathbf{K}$ & B \\
\hline \multicolumn{7}{|l|}{ Aspleniaceae } \\
\hline Asplenium yoshinagae Subsp. Indicum (Sledge) Frazer-Jenk. & $\mathrm{Ep} / \mathrm{L}$ & $\mathrm{V}$ & Patch & + & - & + \\
\hline \multicolumn{7}{|l|}{ Blechnaceae } \\
\hline Blechnum orientale $\mathrm{L}$. & $\mathrm{T}$ & $\mathrm{C}$ & Patch & + & + & + \\
\hline \multicolumn{7}{|l|}{ Cyatheaceae } \\
\hline Cyathea gigantea (Wall. ex Hook.) Holttum & $\mathrm{T}$ & C & Solitary & + & + & + \\
\hline Cyathea nilgirensis Holttum & $\mathrm{T}$ & $\mathrm{E} / \mathrm{NT}$ & Solitary & + & + & + \\
\hline \multicolumn{7}{|l|}{ Davalliaceae } \\
\hline Araiostegia pulchra (D. Don) Copel. & $\mathrm{Ep} / \mathrm{L}$ & C & Patch & + & - & + \\
\hline \multicolumn{7}{|l|}{ Dennstaedtiaceae } \\
\hline Microlepia speluncae (L.) T. Moore & $\mathrm{T}$ & $\mathrm{C}$ & Patch & + & + & + \\
\hline Pteridium aquilinum (L.) Kuhn & $\mathrm{T}$ & $\mathrm{C}$ & Colony & + & + & + \\
\hline \multicolumn{7}{|l|}{ Dryopteridaceae } \\
\hline Arachniodes tripinnata (Goldm.) Sledge & $\mathrm{T}$ & $\mathrm{V}$ & Colony & + & + & + \\
\hline Bolbitis semicordata (Bak.) Ching & $\mathrm{T} / \mathrm{L}$ & $\mathrm{E}$ & Patch & + & + & + \\
\hline Bolbitis subcrenatoides Fraser-Jenk. & $\mathrm{T} / \mathrm{L}$ & $\mathrm{C}$ & Patch & - & + & + \\
\hline \multicolumn{7}{|l|}{ Gleicheniaceae } \\
\hline Dicranopteris linearis (Burm. f.) Underw. & $\mathrm{T}$ & NT & Colony & + & + & + \\
\hline \multicolumn{7}{|l|}{ Lindsaeaceae } \\
\hline Lindsaea ensifolia Sw. & $\mathrm{T}$ & $\mathrm{C}$ & Patch & + & + & + \\
\hline Lindsaea heterophylla Dryand. & $\mathrm{T}$ & $\mathrm{C}$ & Patch & + & - & + \\
\hline Odontosoria chinensis (L.) J. Sm. & $\mathrm{T}$ & $\mathrm{C}$ & Colony & + & + & + \\
\hline \multicolumn{7}{|l|}{ Lomariopsidaceae } \\
\hline Nephrolepis hirsutula (G. Frost.) C. Presl & $\mathrm{T}$ & $\mathrm{C}$ & Colony & + & + & + \\
\hline \multicolumn{7}{|l|}{ Lycopodiaceae } \\
\hline Lycopodiella cernua (L.) Pic. Serm. & $\mathrm{T}$ & $\mathrm{C}$ & Colony & + & + & - \\
\hline \multicolumn{7}{|l|}{ Lygodiaceae } \\
\hline Lygodium flexuosum (L.) Sw. & $\mathrm{T} / \mathrm{Cr}$ & $\mathrm{AR}$ & Patch & + & + & + \\
\hline Lygodium microphyllum (Cav.) R. Br. & $\mathrm{T} / \mathrm{Cr}$ & $\mathrm{AR}$ & Patch & + & + & + \\
\hline Marattiaceae & & & & & & \\
\hline Angiopteris helferiana C. Presl. & $\mathrm{T}$ & $\mathrm{C}$ & Patch & + & + & + \\
\hline Osmundaceae & & & & & & \\
\hline Osmunda huegeliana C. Presl & $\mathrm{T}$ & $\mathrm{E} / \mathrm{NT}$ & Patch & + & + & - \\
\hline Polypodiaceae & & & & & & \\
\hline Drynaria quercifolia (L.) J. Sm. & $\mathrm{L} / \mathrm{Ep}$ & $\mathrm{C}$ & Colony & + & - & - \\
\hline Lepisorus nudus (Hook.) Ching & $\mathrm{L} / \mathrm{Ep}$ & $\mathrm{C}$ & Patch & + & + & + \\
\hline Microsorum membranaceum (D. Don) Ching & $\mathrm{L} / \mathrm{Ep}$ & $\mathrm{C}$ & Solitary & - & - & + \\
\hline Microsorum punctatum (L.) Copel. & $\mathrm{L} / \mathrm{Ep}$ & $\mathrm{C}$ & Patch & + & + & + \\
\hline Pteridaceae & & & & & & \\
\hline Adiantum philippense $\mathrm{L}$. & $\mathrm{T} / \mathrm{L}$ & $\mathrm{C}$ & Colony & + & + & + \\
\hline Adiantum raddianum C. Presl & $\mathrm{T} / \mathrm{L}$ & C & Patch & + & + & + \\
\hline Aleuritopteris anceps (Blanf.) Panigrahi & $\mathrm{T} / \mathrm{L}$ & C & Patch & + & + & + \\
\hline Cheilanthes tenuifolia (Burn. f.) Sw. & $\mathrm{T} / \mathrm{L}$ & $\mathrm{C}$ & Patch & + & + & + \\
\hline Parahemionitis cordata (Roxb. ex Hook. \& Grev.) Fraser-Jenk. & $\mathrm{T} / \mathrm{L}$ & $\mathrm{C}$ & Patch & - & + & + \\
\hline Pityrogramma calomelanos (L.) Link & $\mathrm{T} / \mathrm{L}$ & $\mathrm{C}$ & Patch & + & - & + \\
\hline Pteris argyraea T. Moore & $\mathrm{T}$ & $\mathrm{C}$ & Solitary & - & - & + \\
\hline Pteris biaurita $\mathrm{L}$. & $\mathrm{T}$ & $\mathrm{C}$ & Colony & + & + & + \\
\hline Pteris cameroonian Kuhn & $\mathrm{T}$ & NT & Solitary & - & - & + \\
\hline Pteris confusa T.G. Walker & $\mathrm{T}$ & $\mathrm{C}$ & Colony & + & + & + \\
\hline Pteris quadriaurita Retz. & $\mathrm{T}$ & $E$ & Colony & + & + & + \\
\hline Pteris vittata $\mathrm{L}$. & $\mathrm{T}$ & NT & Patch & - & + & - \\
\hline Selaginellaceae & & & & & & \\
\hline Selaginella delicatula (Desv. ex Poir.) Alston & $\mathrm{T} / \mathrm{L}$ & $\mathrm{C}$ & Patch & + & + & + \\
\hline Selaginella tenera (Hook. \& Grev.) Spring & $\mathrm{T} / \mathrm{L}$ & $E$ & Patch & + & - & + \\
\hline Tectariaceae & & & & & & \\
\hline Tectaria coadunata (J. Sm.) C. Chr. & $\mathrm{T}$ & C & Patch & + & + & + \\
\hline Tectaria polymorpha (Wall. ex Hook.) Copel. & $\mathrm{T}$ & $E$ & Patch & + & + & + \\
\hline
\end{tabular}




\begin{tabular}{llllll}
\hline Thelypteridaceae & & & & \\
\hline Christella dentata (Forssk.) Brownsey \& Jermy & T & C & Colony & + & + \\
\hline Christella parasitica (L.) H. Lév. & T & E & Colony & + & + \\
\hline Macrothelypteris torresiana (Gaudich.) Ching & T & C & Patch & + & + \\
\hline Metathelypteris flaccida (Bl.) Ching & T & C & Colony & + & + \\
\hline Wooddaceae & +
\end{tabular}

\section{Woodsiaceae}

Athyrium hohenackerianum (Kunze)T. Moore $\mathrm{T} / \mathrm{L}$

$\begin{array}{ll}\text { C } & \text { Colony } \\ \text { C } & \text { Solitary }\end{array}$

Note: T- terrestrial; L- Lithophitic; Ep- Epiphytic; Cr- creeper; C- common; R- rare; E- Endemic; Near-threatened- NT; Vulnerable- V; 2KKerekatte and Khalsa range; K- Kudremukh range; B- Belthangadi range. + and - indicates the presence and absence of the pteridophyte, respectively.

and Tectaria polymorpha (Wall. ex Hook.) Copel. of which $C$ nilgirensis and $O$. huegeliana are also listed to be near threatened in the Western Ghats (37). Additionally, five more fern species are reported to be near threatened, which includes Lygodium flexuosum (L.) Sw., Lygodium microphyllum (Cav.) R. Br., D. linearis, Pteris cameroonia Kuhn and Pteris vittata L., while Arachniodes tripinnata (Goldm.) Sledge and Asplenium yoshinagae subsp. indicum (Sledge) Frazer-Jenk. are reported as vulnerable in the Western Ghats $(37,38)$.

The pteridophytes in the study region are terrestrial, epiphytic and lithophytic in habitat. The majority of pteridophytes of the KNP were terrestrial, where $B$. subcrenatoides, $B$. semicordata, S. tenera, Selaginella delicatula (Desv.) Alston, A. philippense, Aleuritopteris anceps (Blanf.) Panigrahi, Parahemionitis cordata (Roxb. ex Hook. \& Grev.) Fraser-Jenk., Pityrogramma calomelanos (L.) Link, Adiantum raddianum Presl, Cheilanthes tenuifolia (Burn. f.) Sw. and Athyrium hohenackranum (Kunze) T. Moore were also seen growing on rocks and rock crevices as lithophytes. Both the species of Lygodiaceae, i.e., Lygodium flexuosum and Lygodium microphyllum were seen growing from the soil as they crept onto any nearest available vertical support as creepers when mature. The species of Polypodiaceae family in the KNP, i.e., Microsorum membranaceum (Don) Ching, Lepisorus nudus (Hook.) Ching, Microsorum punctatum (L.) Copel. and Drynaria quercifolia (L.) J. Sm. are epiphytes, along with Asplenium yoshinagae and Araiostegia pulchra (D. Don) Copel. growing on trees and rocky high grounds.

On the biogeographic level, most of the pteridophyte species are well distributed throughout the ranges of KNP (Table 1). A few species of pteridophytes like Pteris argyraea T. Moore, $P$. cameroonia Kuhn, $P$. vittata L., Diplazium esculentum (Retz.) Sw., M. membranaceum (Don) Ching and $D$. quercifolia (L.) J. Sm. had low distribution and were found only on one range of KNP with human disturbance. They contribute significantly to the biogeographic diversity of the extant pteridophyte flora. Similarly, $P$. argyraea T. Moore, $P$. cameroonia Kuhn and $M$. membranaceum (Don) Ching were only found as a small patch on the Belthangadi range. The occurrence rarity of $P$. vittata was also similar to these pteridophytes and was found as a small patch inhabiting the Kudremukh range. The epiphytic pteridophyte $D$. quercifolia (L.) J. Sm. was seen on tree trunks, well-distributed only in the northern parts of KNP i.e. throughout the Kerekatte and parts of the Khalsa range.

The spatial distribution map derived from the geo-referred dataset obtained from the Phase 1 survey (Fig. 2a) illustrates the uneven distribution of the number of pteridophyte species in KNP. The map depicts the number of different pteridophyte species present at a particular location. The red zones in the map show regions wherein extant pteridophyte species were found to be very low. In contrast, small blue zones exhibit high pteridophyte diversity areas with more than ten different pteridophyte species cohabiting and sharing the same niche. It is observed that the park exhibits green colour, suggesting that the park has three to five uneven distribution of pteridophyte species in this region of the KNP.

\section{Diversity Indices of the extant pteridophytes}

The highest number of different pteridophytes species were found in Megur East at Kerekatte and Khalsa range from the Phase 1 survey. This site was selected for the first transect for Phase 2 survey. A stratified random sampling method was followed. The sampling sites selected for the phase 2 survey are shown in Fig. 1 and mentioned in Suppl. Table 1. Qualitative and quantitative diversity indices of the extant pteridophytes were calculated from Phase 2 survey data, in which a total of 1077 individual sporophytes of pteridophyte were recorded from seven transects laid in the study region.

\section{Qualitative diversity Indices of the extant pteridophyte flora in KNP}

The local landscape of KNP is dominated by pteridophyte species such as $P$. aquilinum and $D$. linearis inhabiting vast grasslands and beneath the tree canopies. Qualitative diversity indices such as Shannon-Wiener diversity index Simpsons Dominance index and evenness index of the KNP pteridophyte flora are presented in Table 2. The Shannon- Wiener diversity index of 3.38 for the region of the study indicated high pteridophyte species diversity. The Simpson's dominance Index for the pteridophyte flora of KNP was 0.96, which indicates the pteridophyte flora although high in diversity, has few dominant representative species. The distribution of pteridophyte species in KNP is uneven with a low evenness value of 0.64 .

Simpson's Dominance Index of the pteridophytes within the ranges of the KNP is very similar. Belthangadi range had the most number of different pteridophyte species (41), followed by Kerekatte and 
Khalsa range (39) and Kudremukh range (37). There was little to no difference in diversity of pteridophytes between Kerekatte and Khalsa Range and Belthangadi Range with Shannon -Wiener Diversity Index values of 3.23 and 3.22 respectively. The less number of pteridophytes present at pteridophytes in KNP are given in Table 3 . The frequency of occurrence of all the fern species in KNP ranged from 0.14 to 0.86 . The chance of occurrence of $A$. raddianum, $P$. argyraea, $P$. calomelanos, $P$ cordata, $P$. cameroonia, $P$. vittata, $D$. esculentum, $M$. membranaceum, L. nudus, $M$. punctatum,
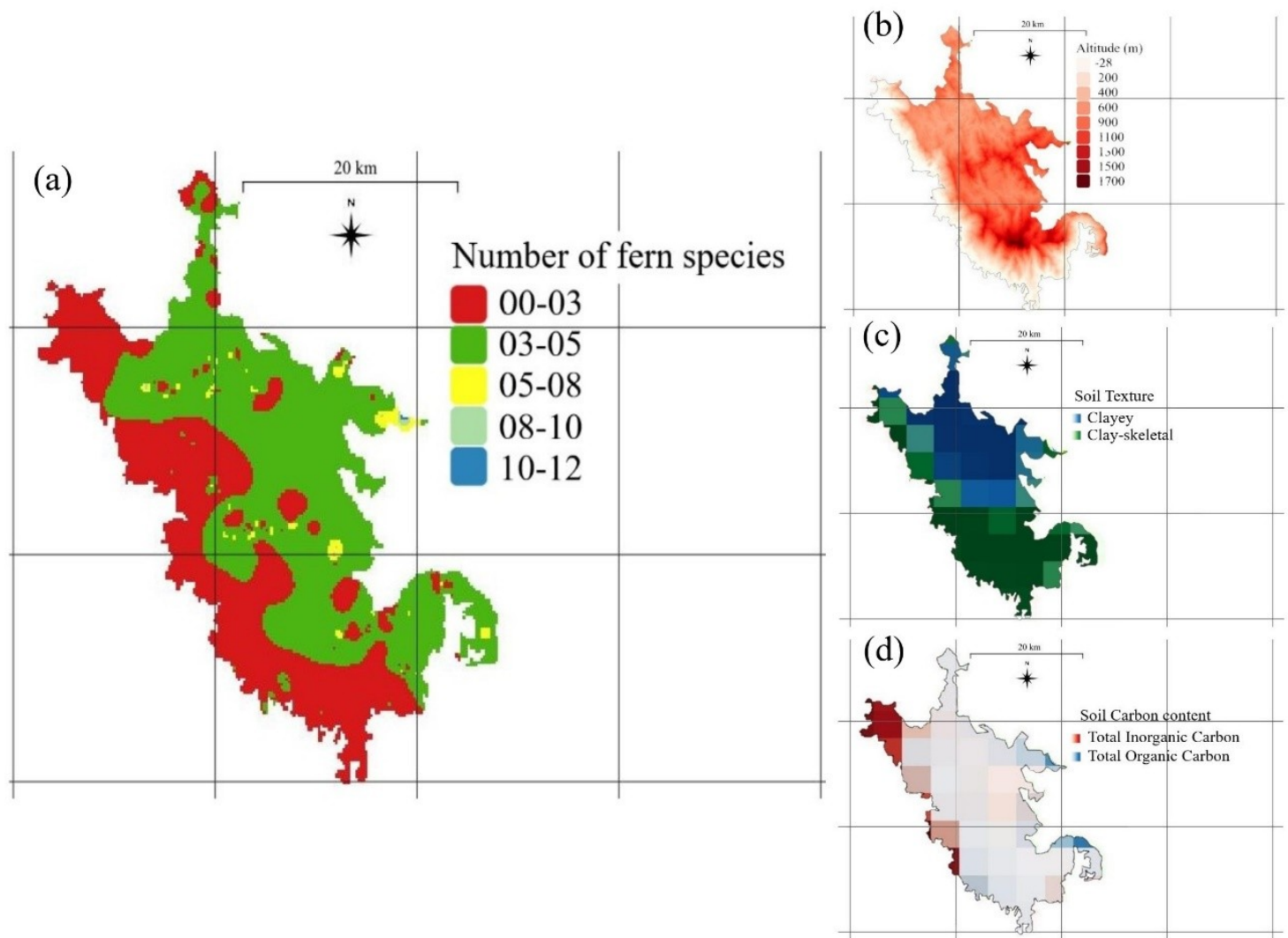

Fig. 2. KNP maps exhibiting (a) Spatial distribution of the number of different pteridophyte species present in KNP, (b) Altitude (c) Soil Texture \& (d) Carbon content.

Table 2. Qualitative diversity indices of extant Pteridophytes of KNP

\begin{tabular}{lcccc}
\hline Diversity index & \multirow{2}{*}{$\begin{array}{c}\text { Kudremukh } \\
\text { National Park } \\
\text { (KNP) }\end{array}$} & & \multicolumn{2}{c}{ Different ranges of KNP } \\
\cline { 3 - 5 } & $\begin{array}{c}\text { Kerekatte and Khalsa } \\
\text { Range }\end{array}$ & Kudremukh Range & Belthangadi Range \\
\hline Total number of species & 46 & 39 & 37 & 41 \\
\hline Simpsons Dominance Index & 0.96 & 0.94 & 0.92 & 0.94 \\
\hline Shannon- Wiener diversity Index & 3.38 & 3.23 & 3.04 & 3.22 \\
\hline Evenness & 0.64 & 0.65 & 0.56 & 0.61
\end{tabular}

Kudremukh range was also depicted by its comparatively lower Shannon -Wiener Diversity Index value (3.04) compared to the other two ranges. The evenness in the distribution of pteridophyte was highest in Kerekatte and Khalsa Range (0.65) followed by Belthangadi range (0.61) and Kudremukh range (0.56).

\section{Quantitative diversity Indices of the extant pteridophyte flora in KNP.}

The calculated quantitative diversity indices, i.e. Frequency (F), Density (D), Abundance (A), Relative Abundance (RA) and Important Value Index (IVI) along with its distribution pattern of the extant
Macrothelypteris torrensiana, $M$. speluncae and Araiostegia pulchra was least (0.14). P. aquilinum also known as the bracken fern reported to be an invasive weed (15) occurred most frequently along with $A$. philippense, $P$. biaurita, Athyrium hohenackranum, and $B$. orientale with a frequency of 0.85 . D. linearis was the most abundant species in KNP with an abundance value of 20 followed by $P$. aquilinum (15.83), while D. esculentum and $M$. membranaceum were the least abundant species found in the studied transects of KNP. Abundance does not give a total picture of the numerical strength of a species as it considers only the occurrence of a species within the transects. Therefore, relative values to the total 
Table 3. Quantitative diversity indices of Pteridophytes in KNP.

\begin{tabular}{|c|c|c|c|c|c|c|}
\hline Species & $\mathbf{F}$ & D & A & RA & IVI & $\begin{array}{c}\text { Distribution } \\
\text { pattern }\end{array}$ \\
\hline Adiantum philippense L. & $0.86^{\mathrm{E}}$ & 7.0 & 8.17 & 2.53 & 11.77 & $\mathrm{C}_{1}$ \\
\hline Adiantum raddianum C. Presl & $0.14^{\mathrm{A}}$ & 2.0 & 14.0 & 4.34 & 6.40 & $\mathrm{R}$ \\
\hline Aleuritopteris anceps (Blanf.) Panigrahi & $0.43^{\mathrm{c}}$ & 1.71 & 4.0 & 1.24 & 4.70 & $\mathrm{C}_{1}$ \\
\hline Angiopteris helferiana C. Presl. & $0.43^{\mathrm{C}}$ & 2.43 & 5.67 & 1.76 & 5.68 & $\mathrm{R}_{1}$ \\
\hline Arachniodes tripinnata (Goldm.) Sledge & $0.28^{\mathrm{B}}$ & 1.71 & 6.0 & 1.86 & 4.50 & $\mathrm{R}_{1}$ \\
\hline Araiostegia pulchra (D. Don) Copel. & $0.14^{\mathrm{A}}$ & 0.43 & 3.0 & 0.93 & 1.97 & $\mathrm{R}_{1}$ \\
\hline Asplenium yoshinagae Subsp. Indicum (Sledge) Frazer-Jenk. & $0.28^{\mathrm{B}}$ & 1.43 & 5.0 & 1.55 & 4.00 & $\mathrm{C}_{1}$ \\
\hline Athyrium hohenackerianum (Kunze)T. Moore & $0.86^{\mathrm{E}}$ & 9.86 & 11.5 & 3.56 & 14.66 & $\mathrm{C}_{1}$ \\
\hline Blechnum orientale L. & $0.86^{\mathrm{E}}$ & 12.86 & 15.0 & 4.65 & 17.69 & $\mathrm{C}_{1}$ \\
\hline Bolbitis semicordata (Bak.) Ching & $0.57^{\mathrm{C}}$ & 6.14 & 10.75 & 3.33 & 10.43 & $\mathrm{C}_{1}$ \\
\hline Bolbitis subcrenatoides Fraser-Jenk. & $0.28^{\mathrm{B}}$ & 2.43 & 8.5 & 2.63 & 5.74 & $\mathrm{R}_{1}$ \\
\hline Cheilanthes tenuifolia (Burn. f.) Sw. & $0.43^{\mathrm{C}}$ & 3.14 & 7.33 & 2.27 & 6.66 & $\mathrm{C}_{1}$ \\
\hline Cyathea gigantea (Wall. ex Hook.) Holttum & $0.43^{\mathrm{c}}$ & 1.86 & 4.33 & 1.34 & 4.89 & $\mathrm{C}_{1}$ \\
\hline Cyathea nilgirensis Holttum & $0.28^{\mathrm{B}}$ & 1.43 & 5.0 & 1.55 & 4.00 & $\mathrm{C}_{1}$ \\
\hline Christella dentata (Forssk.) Brownsey \& Jermy & $0.71^{\mathrm{D}}$ & 7.57 & 10.6 & 3.29 & 12.08 & $\mathrm{C}_{1}$ \\
\hline Christella) parasitica (L.) H. Lév. & $0.71^{\mathrm{D}}$ & 9.0 & 12.6 & 3.91 & 13.62 & $\mathrm{C}_{1}$ \\
\hline Dicranopteris linearis (Burm. f.) Underw. & $0.43^{\mathrm{C}}$ & 8.57 & 20.0 & 6.2 & 14.11 & $\mathrm{R}$ \\
\hline Diplazium esculentum (Retz.) Sw. & $0.14^{\mathrm{A}}$ & 0.14 & 1.0 & 0.31 & 1.17 & $\mathrm{C}_{1}$ \\
\hline Drynaria quercifolia (L.) J. Sm. & $0.28^{\mathrm{B}}$ & 1.43 & 5.0 & 1.55 & 4.00 & $\mathrm{C}_{1}$ \\
\hline Lepisorus nudus (Hook.) Ching & $0.14^{\mathrm{A}}$ & 0.71 & 5.0 & 1.55 & 2.78 & $\mathrm{R}_{1}$ \\
\hline Lindsaea heterophylla Dryand. & $0.28^{\mathrm{A}}$ & 1.14 & 4.0 & 1.24 & 3.51 & $\mathrm{C}_{1}$ \\
\hline Lindsaea ensifolia Sw. & $0.43^{\mathrm{C}}$ & 3.57 & 8.33 & 2.58 & 7.25 & $\mathrm{C}_{1}$ \\
\hline Lycopodiella cernua (L.) Pic. Serm. & $0.28^{\mathrm{B}}$ & 0.43 & 1.5 & 0.46 & 2.27 & $\mathrm{C}_{1}$ \\
\hline Lygodium flexuosum (L.) Sw. & $0.43^{\mathrm{C}}$ & 2.86 & 6.67 & 2.07 & 6.27 & $\mathrm{C}_{1}$ \\
\hline Lygodium microphyllum (Cav.) R. Br. & $0.43^{\mathrm{c}}$ & 0.71 & 1.67 & 0.52 & 3.32 & $\mathrm{C}_{1}$ \\
\hline Macrothelypteris torresiana (Gaudich.) Ching & $0.14^{\mathrm{A}}$ & 1.43 & 10.0 & 3.1 & 4.79 & $\mathrm{R}$ \\
\hline Microlepia speluncae (L.) T. Moore & $0.14^{\mathrm{A}}$ & 0.57 & 4.0 & 1.24 & 2.37 & $\mathrm{R}_{1}$ \\
\hline Microsorum membranaceum (D. Don) Ching & $0.14^{\mathrm{A}}$ & 0.14 & 1.0 & 0.31 & 1.17 & $\mathrm{C}_{1}$ \\
\hline Microsorum punctatum (L.) Copel. & $0.14^{\mathrm{A}}$ & 0.43 & 3.0 & 0.93 & 1.97 & $\mathrm{R}_{1}$ \\
\hline Nephrolepis hirsutula (G. Frost.) C. Presl & $0.43^{\mathrm{C}}$ & 1.71 & 4.0 & 1.24 & 4.70 & $\mathrm{C}_{1}$ \\
\hline Odontosoria chinensis (L.) J. Sm. & $0.43^{\mathrm{C}}$ & 3.29 & 7.67 & 2.38 & 6.86 & $\mathrm{C}_{1}$ \\
\hline Osmunda huegeliana C. Presl & $0.28^{\mathrm{B}}$ & 0.86 & 3.0 & 0.93 & 3.01 & $\mathrm{C}_{1}$ \\
\hline Parahemionitis cordata (Roxb. ex Hook. \& Grev.) Fraser-Jenk. & $0.14^{\mathrm{A}}$ & 0.57 & 4.0 & 1.24 & 2.37 & $\mathrm{R}_{1}$ \\
\hline Pityrogramma calomelanos (L.) Link & $0.14^{\mathrm{A}}$ & 1.57 & 11.0 & 3.41 & 5.19 & $\mathrm{R}$ \\
\hline Pteridium aquilinum (L.) Kuhn & $0.86^{\mathrm{E}}$ & 13.57 & 15.83 & 4.91 & 18.41 & $\mathrm{C}_{1}$ \\
\hline Pteris argyraea T. Moore & $0.14^{\mathrm{A}}$ & 0.29 & 2.0 & 0.62 & 1.57 & $\mathrm{C}_{1}$ \\
\hline Pteris biaurita $\mathrm{L}$. & $0.86^{\mathrm{E}}$ & 6.71 & 7.83 & 2.43 & 11.48 & $\mathrm{C}_{1}$ \\
\hline Pteris cameroonian Kuhn & $0.14^{\mathrm{A}}$ & 0.29 & 2.0 & 0.62 & 1.57 & $\mathrm{C}_{1}$ \\
\hline Pteris confusa T. G. Walker & $0.71^{\mathrm{D}}$ & 5.43 & 7.6 & 2.36 & 9.75 & $\mathrm{C}_{1}$ \\
\hline Pteris quadriaurita Retz. & $0.71^{\mathrm{D}}$ & 6.29 & 8.8 & 2.73 & 10.68 & $\mathrm{C}_{1}$ \\
\hline Pteris vittata $\mathrm{L}$. & $0.14^{\mathrm{A}}$ & 0.29 & 2.0 & 0.62 & 1.57 & $\mathrm{C}_{1}$ \\
\hline Selaginella tenera (Hook. \& Grev.) Spring & $0.71^{\mathrm{D}}$ & 4.86 & 6.8 & 2.11 & 9.13 & $\mathrm{C}_{1}$ \\
\hline Selaginella delicatula (Desv. ex Poir.) Alston & $0.43^{\mathrm{c}}$ & 5.14 & 12.0 & 3.72 & 9.41 & $\mathrm{R}_{1}$ \\
\hline Tectaria coadunata (J. Sm.) C. Chr. & $0.28^{\mathrm{B}}$ & 2.14 & 7.5 & 2.32 & 5.24 & $\mathrm{R}_{1}$ \\
\hline Tectaria polymorpha (Wall. ex Hook.) Copel. & $0.43^{\mathrm{C}}$ & 2.71 & 6.33 & 1.96 & 6.07 & $\mathrm{C}_{1}$ \\
\hline Metathelypteris) flaccida (Bl.) Ching & $0.43^{\mathrm{C}}$ & 5.0 & 11.67 & 3.62 & 9.21 & $\mathrm{R}_{1}$ \\
\hline
\end{tabular}

Note: F- Frequency, A- Abundance, D- Density, IVI- Importance value index, RA- Relative abundance; R- regular, $\mathrm{R}_{1}$ is random, $\mathrm{C}_{1}$ is contagious; The Raunkiaer's frequency classes are A, B, C, D and E.

abundance of all the species in all sampled transects are indicative of the actual numerical strength of a species (31). The rigorous weedy growth of $P$. aquilinum throughout the area resulted in the highest relative abundance value of 8.82 , followed by $D$. linearis (8.36) in the KNP. At the same time, the least abundant pteridophyte species was $\mathrm{M}$. membranaceum with a relative abundance of 0.009 followed by three species of Pteridaceae family viz., $P$. argyraea, $P$. cameroonia and $P$. vittata with relative abundance value of 0.19 . The endemic pteridophyte species of Western Ghats i.e. S. tenera, O. huegeliana, $P$. quadiaurita, B. subcrenatoides, B. semicordata, $C$. nilgirensis, C. paracitica and T. polymorpha were abundant in KNP with high RA. P. aquilinum (13.57) followed by $B$. orientale (12.86) were the most densely distributed pteridophyte species, whereas $D$. esculentum and $M$. membranaceum were the least densely distributed species (0.14) in KNP.

IVI helps in understanding the ecological significance of the species irrespective of vegetation type; hence greater IVI values indicate the higher ecological significance of the species compared to others in a particular ecosystem (31). The IVI values of the extant pteridophyte community ranged from 18.41 for $P$. aquilinum to 1.17 for $D$. esculentum and M. membranaceum. Pteridophyte species with highest IVI values varied on different ranges of KNP. $B$. orientale and $P$. aquilinum inhabited in Khalsa \& Kerekatte range and Kudremukh range with highest IVI values of 13.48 and 36.66 respectively. Two fern species namely, $B$. semicordata and $C$. dentata present in Belthangadi range had the highest IVI value (19.64) 
among the pteridophyte flora. According to calculated distribution pattern for pteridophyte flora (Table 3), four species of ferns i.e. D. linearis, $A$. raddianum, $P$. calomelanos and $M$ torrensiana were regularly distributed in their respective habitats, while other species where either random or contagiously distributed.

The extant pteridophyte flora of KNP where grouped into Raunkiaer's frequency classes. The species distribution for the classes A, B, C, D and E, was 28, 20, 30,11 and $11 \%$ respectively. The obtained frequency distribution curve was then compared to the "normal" frequency curve (Fig. 3). The curve of frequency of the extant fern distribution in KNP indicates that the pteridophyte flora in the park is non-homogenous. The floristic uniformity varies directly with the proportionate size of classes A and E (39). In contrast, when the classes $\mathrm{B}, \mathrm{C}, \mathrm{D}$ are relatively high, the stand reflects a non-homogenous distribution. The typical frequency ratio is useful in many kinds of studies in testing the uniformity of vegetation. Essentially class $\mathrm{E}$ should be larger than class $\mathrm{D}$ for vegetation to be of uniform distribution (40). Classes D and E are equal in the current study indicating non-homogeneity in pteridophyte distribution.

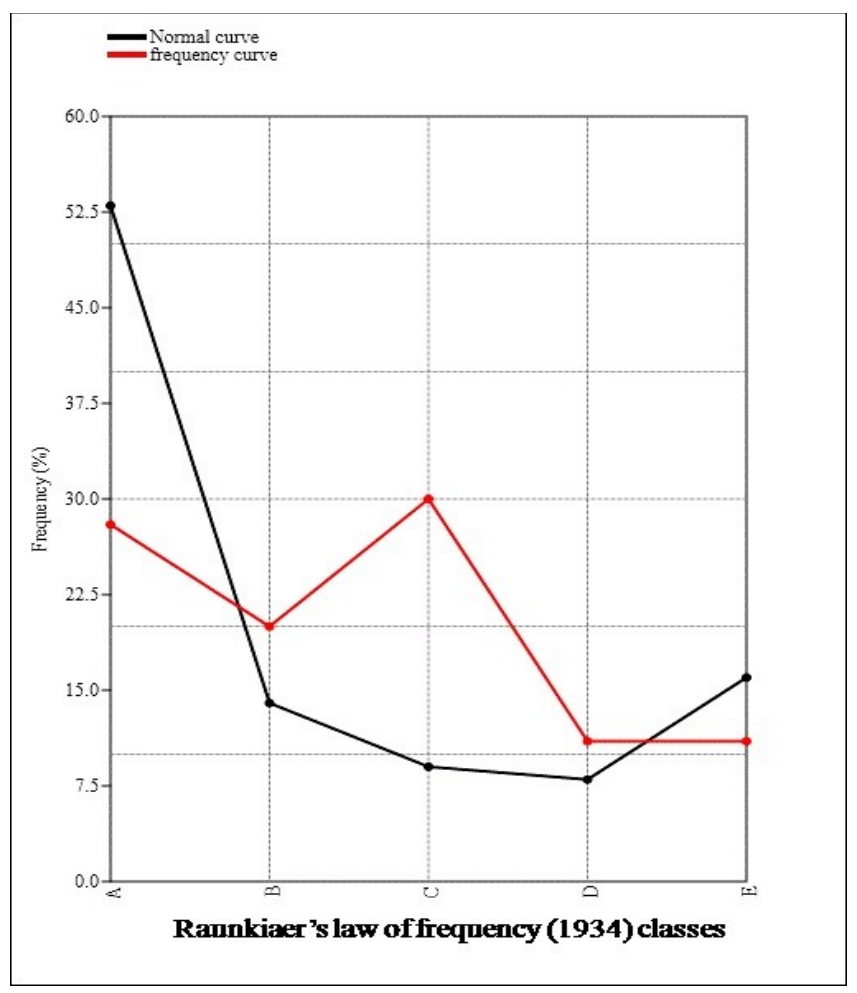

Fig. 3. Frequency classes. Note: The black line indicates the "normal" curve of frequency while the curve in red is the frequency curve of pteridophytes in KNP.

\section{Discussion}

Biodiversity inventories are used to determine the nature and distribution of forest biodiversity and resources along with the forest structure for developing effective forest conservation and management plans $(41,42)$. While the preliminary survey (17) noted only 37 species of pteridophytes, the diversity survey in the current study revealed a rich and diverse pteridophyte flora with 46 different pteridophyte species in the KNP. A similar number of extant pteridophyte species were reported in other regions from the Western Ghats such as Aralam Wildlife Sanctuary (12) consisting of 63 species and Kemmangundi forest with 38 species (14). The extant pteridophytes of KNP ranged from creepers and epiphytes such as Lygodium and Asplenium species to terrestrial pteridophyte species of Pteridium. Shannon-Wiener Diversity Index is an expression of community structure and complexity of habitat (13). A high index value obtained in the study suggests a more diverse and established pteridophyte community. Various studies conducted in different forests of Kigga (13), Chillapatta (31), Banajalaya (43), and Mudige (44) also showed a similarly high Shannon-Wiener Diversity Index of 2.81, 1.79, 1.57 and 2.66 respectively. Although the pteridophyte flora in KNP is highly diverse, the high Simpsons dominance index value of 0.94 along with a low evenness index value of 0.64 indicates that the individual species are infrequent and a couple of the extant pteridophyte species dominate the KNP. The pteridophyte diversity in wet evergreen forests of Sakleshpur in the central Western Ghats (45) also exhibited analogous pteridophyte species dominating the area indicating that it is not uncommon for pteridophytes for a few representative species to dominate an area numerically.

It is evident from the results that $P$. aquilinum dominated the KNP with high abundance, density, and frequency values. Reports suggest that $P$. aquilinum is not found on the Indian subcontinent (46). However, $P$. aquilinum has been reported in different parts of western India by several researchers $(29,47,48)$. In the present study, we have retained the identity of the said pteridophyte as $P$. aquilinum, as per the treatment of the taxonomic key and digital protologue followed by a DNA barcoding (unpublished) data. Furthermore, molecular identification of the specimen will be accomplished and reported in the future. $P$. aquilinum is reported as the fifth most distributed weed species of the world (49). The dominance of such a weed pteridophyte results in a decrease in other species such as grasses which otherwise is fodder for the forest herbivores (50). Several studies have been conducted to control this invasive pteridophyte (51) and hence, immediate attention and the preventive measures are recommended for its timely control.

The species that dominate the surroundings contribute more to the microenvironment within the forest, but the uncommon or rare species contribute primarily to the species structure of the forest (52). Some of the threatened and near threathened pteridophyte species in the Western Ghats are frequently found in low abundance in the KNP. Species such as L. flexuosum and $D$. linearis are abundant in the study area, which is otherwise reported to be at risk in the Western Ghats. Ferns such as $P$. argyraea, $P$. cameroonia and $P$. vittata are low in relative abundance and frequency of occurrence in the KNP along with endemic species such as $O$. huegeliana and $C$. nilgirensis. Fern species such as $D$. esculentum and $M$. membranaceum were 
also found to have very low distribution density. Indicating endemic, rare and endangered pteridophytes present in KNP are limited. The hotspot is likely to face the disappearance of its diverse pteridophyte flora to weedy species (53) such as $P$. aquilinum and $D$. linearis in the study area.

The distribution data of all the pteridophytes present in the study region with the spatial distribution map of number of species (Fig. 2a) along with the curve of frequency (Fig. 3) indicates the pteridophytes were distributed unevenly across the KNP with certain high diversity regions with more than ten different species in the same location. It is evident that pteridophytes are a diverse group of plants that occupy discrete niches in the forests dominated mainly by trees and shrubs (54) which results in the formation of niches with high or low pteridophyte diversity. These differences in diversity of pteridophytes within the park could be due to the biogeographic relationship the pteridophytes share with its surroundings (55). Amongst various reasons for the non-homogeneous distribution of floral diversity (56) pteridophyte biogeography may be directly linked to prevalent abiotic factors. Contiguous distribution is typical in nature (57) and formed due to small but significant variations in ambient environmental conditions, while random distribution is found in uniform environments (58$60)$. The variation in altitude, shola vegetation and regional topography of KNP may be the reason for such variation in distribution. To understand this unevenness, we compared the distribution of fern species to the data of variation in altitude, soil texture and soil carbon content (organic and inorganic carbon), obtained from the Indian geo-platform of ISRO- Bhuvan (Bhuvan.nrsc.gov.in). The most of the area in the west of the KNP where in the number of fern species is very low coincides with steep slopes and high change in altitude, while the same area is dominated by clay-skeletal soil and total inorganic Carbon content (Fig. 2(b-d)). A small area on the east of KNP with highest number of fern species, has gradual or no steep change in altitude, clay soil texture and high soil organic carbon content. However further study in this area is required to validate the same. Many researchers have studied the reasons for such non-homogeneous pteridophyte flora distributions which is mostly affected by other distinguished abiotic factor depending on the habitat (61) and environmental correlates (62) such as edaphic factors (63), moisture availability (64), topography (65) and elevation (66). Therefore, to understand the reasons for such varying and nonhomogeneous pteridophyte diversity in KNP, environmental correlates and other edaphic factors need to be studied.

\section{Conclusion}

Kudremukh National Park exhibited rich and highly diverse non-homogenous, unevenly distributed extant Pteridophyte flora. The Belthangadi range at the southern region of the KNP showed greater diversity as compared to the other two studied regions of Kerekatte and Khalsa range and Kudremukh range. The study region was dominated by a few unambiguous pteridophyte species $D$. linearis and $P$. aquilinum with a high Simpson's dominance index of 0.96 , indicating their weedy nature. In contrast, other species were infrequently and unevenly distributed. There is an urgent need to take preventive measures to control the fast-growing dominant species of $D$. linearis and $P$. aquilinum. Among the pteridophyte species found in the KNP, eight are endemic while nine reported to be rare, threatened or at risk in the Western Ghats. It is necessary for these threatened species, to maintain and conserve the regions of their respective habitats and restrict anthropogenic activities. Few regions with high fern diversity in the KNP demonstrated regions that are highly favourable for pteridophyte populations. Further, studies on the influence of edaphic and other factors on pteridophyte distribution and diversity, need to be conducted in KNP to understand the distribution and diversity patterns found in the current study.

\section{Acknowledgements}

Our sincere thanks to DCF, KNP, Karkala; Rev Fr Swebert D'Silva SJ, Principal St Aloysius College (Autonomous), Dr Asha Abraham, HOD, Department of Post Graduate Studies and Research in Biotechnology, St Aloysius College, Mangalore, Karnataka and Rev Fr Dr Leo D'Souza SJ, Director, Dr Küppers Laboratory of Applied Biology, St Aloysius College for providing the research facilities.

\section{Authors' contributions}

SH provided the intellectual input, resources and guidance for the research carried out. SM executed the wet lab research, field collection surveys, data analysis, manuscript preparation and prepared all figures and tables. All authors reviewed the manuscript.

\section{Conflict of interests}

The authors declare no competing interest.

\section{Supplementary files}

Table 1. Details of fern sampling sites as shown in Fig. 1 for enumeration of different fern species in KNP.

\section{References}

1. Kenrick P, Crane PR. The origin and early evolution of plants on land. Nature. 1997;389:33-39. https://doi.org/10.1038/37918

2. Dudani SN, Chandran MDS, Mahesh MK, Ramachandra TV Diversity of Pteridophytes of Western Ghats. Sahyadri E-News. 2011; 3: 2-34.

3. Dixit RD. Conspectus of Pteridophytic diversity in India. Indian Fern Journal. 2000;17:77 - 91.

4. Rodgers WA, Panwar SH. Biogeographical Classification of India. Dehradun: New Forest; 1988.

5. Pascal JP. Wet Evergreen Forests of the Western Ghats of India. Pondichéry: Institut français de Pondichéry; 1988. 
6. Gimaret-Carpentier C, Dray S, Pascal JP. Broad-scale biodiversity pattern of the endemic tree flora of the Western Ghats (India) using canonical correlation analysis of herbarium records. Ecography. 2003;26:429-44. https://doi.org/10.1034/j.1600-0587.2003.03356.x

7. Manickam VS, Irudayaraj V. Pteridophyte flora of the Western Ghats - South India. New Delhi: BI Publications Pvt Ltd; 1992.

8. Patil S, Mahamuni R, Dongare M. Diversity of ferns in the hills of northern Western Ghats, Maharashtra, India. Indian Fern Journal. 2012;29:158-63.

9. Patil S, Lavate R, Rawat V, Dongare M. Diversity and distribution of Pteridophytes from Satara District, Maharashtra (India). Plant Science Today. 2016;3(2):149-56.

10. Datar MN, Lakshminarasimhan P. Habitat based Pteridophyte diversity from Western Ghats of Goa, India. Phytotaxonomy. 2010; 10:70-76

11. Sukumaran S, Jeeva S, Raj ADS. Diversity of Pteridophytes in miniature sacred forests of Kanyakumari District, Southern Western Ghats. Indian Journal of forestry. 2009;32(2):285-90.

12. Vijisha P, Rajesh KP. Pteridophyte Flora of Aralam Wildlife Sanctuary, Kerala - A Preliminary Analysis. Cryptogam Biodiversity and Assessment. 2016;1(1):71-74.

13. Deepa J, Parashurama TR, Krishanappa M, Nataraja S. Distribution of Pteridophytes in Kigga forest, Central western Ghats, Karnataka, South India. Indian Fern Journal. 2013a;30:18-24.

14. Deepa J, Parashurama TR, Krishanappa M, Nataraja S. Pteridophytic flora of Kemmangundi forest, Karnataka, South India. Annals of Plant Sciences. 2013b;2(11):484-88.

15. Patil S, Dongare M. Enumerative checklist of pteridophytes from Satara district (MH), India. Plant Science Today. 2017;4(3):75-87.

16. Desai M. Western Ghats: Challenges of Sustainable Development [Internet]. Press Information Bureau; 2012 [cited 2015 Jan 12]. Available from https://pib.gov.in/newsite/mbErel.aspx?relid=85175

17. Hegde S, Sajeev S. A Collection of Selected Ferns of Karnataka Mangalore, Assisi Press; 2013.

18. Brooks TM, Mittermeier RA, da Fonseca GAB et al. Global biodiversity conservation priorities. Science. 2006;313:58-61. https://doi.org/10.1126/science.1127609

19. Kier G, Kreft H, Lee TM et al. A global assessment of endemism and species richness across islands and mainland regions. Proceedings of the National Academy of Science USA. 2009;106:9322-27. https://doi.org/10.1073/pnas.0810306106

20. Hernandez-Stefanoni JL, Ponce-Hernandez R. Mapping the spatial distribution of plant diversity indices in a tropical forest using multi-spectral satellite image classification and field measurement. Biodiversity and Conservation. 2004;13: 2599-21. https://doi.org/10.1007/s10531-004-2137-2

21. Dogan HM, Dogan M. A new approach to diversity indices modelling and mapping plant biodiversity of Nallihan (A3Ankara/Turkey) forest ecosystem in frame of geographic information systems. Biodiversity and Conservation. 2006;15:855-78. https://doi.org/10.1007/s10531-004-2937-4

22. Ramirez-Barahona S, Luna-Vega I, Tejero-Diez D. Species richness, endemism and conservation of American tree ferns (Cyatheales). Biodiversity and Conservation. 2011;20:59-72. https://doi.org/10.1007/s10531-010-9946-2

23. Lehmann A, Leathwick JR, Overton JM. Assessing New Zealand fern diversity from spatial predictions of species assemblages. Biodiversity and Conservation. 2002; 11: 2217-38.

24. Beddome, R.H. Handbook To The Ferns Of British India, Ceylon And The Malay Peninsula. New Delhi: Today and Tomorrow's Printers and Publishers; 1883.

25. Madhusoodanan PV. Handbook Of Ferns And Fern Allies Of Kerala. Kozhikode: Prasad Printers; 2015.

26. Bhat KG, Rajagopal PK. Pteridophytes Of Karnataka State, India. Udupi: Vinayaka Prakashana; 2016.
27. Maden K. Plant Collection and Herbarium Techniques. Our Nature. 2014;2:53-57.

28. Maridass M, Raju G. Conservation status of Pteridophytes, Western Ghats, South India. Indian Journal of Biotechnology. 2010; 1(Special Issue): 42-57.

29. Shaikh S. Status of some important pteridophytes from the parts of Northern Western Ghats of Maharashtra, India International Research Journal of Biological Sciences. 2017;6(1):47-49.

30. Tuomisto H, Poulsen AD. Pteridophyte diversity and species composition in four Amazonian rain forests. Journal of Vegetation Science. https://doi.org/10.2307/3236631

31. Shukla G, Chakravarty S. Fern diversity and biomass at Chilapatta reserve forest of West Bengal Terai Duars in subhumid tropical foothills of Indian eastern Himalayas. Journal of Forestry Research. 2012;23(4):609-13. https://doi.org/10.1007/s11676-012-0301-1

32. Simpson EH. Measurement of diversity. Nature. 1949;163:688.

33. Shannon CE, Wiener, W. The Mathematical Theory of Communication. Urbana: University of Juionis Press; 1963.

34. Pielou EC. Ecological Diversity. New York: John Wiley and Sons; 1975

35. Cottam G, Curtis JT. The Use of Distance Measures in Phytosociological Sampling. Ecology. 1956;37(3):451-60. https://doi.org/10.2307/1930167

36. Raunkiaer C. The Life Forms Of Plants And Statistical Geography. Oxford, Claredon; 1934. 623p.

37. Chandra S, Fraser-Jenkins CR, Kumari A, Srivastava AA Summary of the Status of Threatened Pteridophytes of India. Taiwania.

https://doi.org/10.6165/tai.2008.53(2).170

38. Fraser-Jenkins CR. Endemics and pseudo-endemics in relation to the distribution patterns of Indian Pteridophytes. Taiwania. 2008; 53(3): 264-92. https://doi.org/10.6165/tai.2008.53(3).264

39. Oosting HJ. The Study Of Plant Communities: An Introduction To Plant Ecology. 2nd ed. San Fransisco: Freeman and Company; 1958.

40. Hanson HC, Churchill, ED. The Plant Communities. New York: Reinhold Publishing Corporation; 1961.

41. Farhadi P, Soosani J, Alijani V, Adeli K. Comparison of the Quercus brantii and Pyrus glabra Boiss Species Structure in Zagros Forests (Case Study: Ghalehgol Forest, Khoramabad City, Iran). International Journal of Biological Sciences. 2013;3:210-17.

42. Sagar R, Raghubanshi A, Singh J. Tree species composition, dispersion and diversity along a disturbance gradient in a dry tropical forest region of India. Forest Ecology and Management. 2003;186:61-71. https://doi.org/10.1016/S03781127(03)00235-4

43. Ashwini S, Parashurama TR. Pteridophytic Composition in Banajalaya Forest Region, Karnataka, South India International Journal of Science and Research. 2011;3(10):95457.

44. Parashurama TR, Deepa J, Kariyajjanavar P. Pteridophyte diversity in mudigere taluk, Central Western Ghats, Karnataka, South India. International Journal of Current Research 2016;8(10):40339-42.

45. Dudani SN, Mahesh MK, Chandran MDS, Ramachandra TV Pteridophyte diversity in wet evergreen forests of Sakleshpur in central Western Ghats. Indian Journal of Plant Sciences. 2014;3(1):28-39.

46. Ranil RHG, Pushpakumara G, Fraser-Jenkins CR, Wijesundara S. Misidentification of Pteridium revolutum (Blume) Nakai as an invasive alien in Sri Lanka. In: Marabe B, Silva P, Wijesundara DSA, Atapattu N, editors. Invasive Alien Species: Strengthening Capacity to Control Introduction and Spread in Sri Lanka. Colombo, Biodiversity Secretariat, Ministry of Environment, Colombo; 2010. 141-49 p. 
47. Behera SK, Khare PB. First report of pteridophytes from Govind Wildlife Sanctury, Uttarkashi, Uttarakhand, India. Tropical Plant Research. 2014;1(2):37-47.

48. Benjamin A, Manickam VS. Medicinal pteridophytes from Western Ghats. Indian Journal of Traditional knowledge. 2007; 6(4): $611-18$

49. Vetter J. A biological hazard of our age: bracken fern [Pteridium aquilinum (L.) Kuhn]-a review. Acta Vet Hung. 2009; 57(1): 183-96. https://doi.org/10.1556/AVet.57.2009.1.18

50. Girijashankar S. A fern turning into a weed poses a threat to Kudremukh grass. The Times of India [Internet]. 2012 Dec 18 [cited 2015 Jan 7]. Available from: https://timesofindia.indiatimes.com/city/mysuru/A-fernturning-into-a-weed-poses-a-threat-to-Kudremukh-grasslands/ articleshow/17659462.cms

51. Stewart G, Cox E, Duc ML, Pakeman R, Pullin A, Marrs R Control of Pteridium aquilinum: Meta-analysis of a Multi-site Study in the UK. Annals of Botany. 2008;101:957-70. https://doi.org/10.1093/aob/mcn020

52. Cao M, Zhang J. Tree species diversity of tropical forest vegetation in Xishuangbanna, SW China. Biodiversity and Conservation. https://doi.org/10.1023/A:1018367630923

1997;6:995-1006.

53. Osipova E, Shadie P, Zwahlen C, et al. IUCN World Heritage Outlook 2: A Conservation Assessment Of All Natural World Heritage Sites. Gland, Switzerland: IUCN. 2017; pp 92;. https://doi.org/10.2305/IUCN.CH.2017.17.en

54. Morajkar S, Sajeev S, Hegde S. Ferns: a thriving group of urban dwellers. Bionature. 2015;35:13-21.

55. Tryon R. The Biogeography of Species, with Special Reference to Ferns. Botanical Review. 1986;52(2):117-56.

56. Barrington DS. Ecological and historical factors in fern biogeography. Journal of Biogeography. 1993;20:275-79. https://doi.org/10.2307/2845635

57. Odum EP. Fundamentals of Ecology. W.B. Philadelphia, Saunders and Co; 1971.

58. Rawat B, Negi VS, Mishra J, Tewari LM. The potential contribution of wildlife sanctuary to forest conservation: a case study from Binsar Wildlife Sanctuary. Journal of Molecular $\quad$ Sciences. 2013;10(5):854-65. https://doi.org/10.1007/s11629-013-2514-y

59. Kumar M, Sharma CM, Rajwar GS. A study on the community structure and diversity of a sub-tropical forest of Garhwal Himalayas. Indian Forester. 2004;130:207-14.

60. Mandal G, Joshi SP. Analysis of vegetation dynamics and phytodiversity from three dry deciduous forests of Doon
Valley, Western Himalaya, India. Journal of Asia-Pacific Biodiversity.

https://doi.org/10.1016/j.japb.2014.07.006 2014;7:292-304.

61. Greer G, Lloyd RM, McCarthy BC. Factors influencing the distribution of pteridophytes in a south-eastern Ohio hardwood forest. Journal of the Torrey Botanical Society. 1997;124:11-21. https://doi.org/10.2307/2996594

62. Lwanga JS, Balmford A, Badaza R. Assessing fern diversity: relative species richness and its environmental correlates in Uganda. Biodiversity and Conservation. 1998;7:1387-98.

63. Tuomisto H, Kalle R. Distribution of Pteridophyta and Melastomataceae along an edaphic gradient in an Amazonian rain forest. Journal of Vegetation Science. 1993; 4: 25-34. https://doi.org/10.2307/3235634

64. Karst J, Gilbert B, Lechowicz MJ. Fern community assembly: the roles of chance and the environment at local and intermediate scale. Ecology. 2005; 86: 2473-86. https://doi.org/10.1890/04-1420

65. Nettesheim FC, Damasceno ER, Sylvestre LS. Different slopes of a mountain can determine the structure of ferns and lycophytes communities in a tropical forest of Brazil. Annals of the Brazilian Academy of Sciences. 2014;86(1):199-210. http://dx.doi.org/10.1590/0001-3765201495912

66. Salazar L, Homeier J, Kessler M, et al. Diversity patterns of ferns along elevational gradients in Andean tropical forests. Plant Ecology and Diversity. 2013;8:13-24. https://doi.org/ 10.1080/17550874.2013.843036

Additional information

Peer review information: Plant Science Today thanks Sectional Editor and the other anonymous reviewers for their contribution to the peer review of this work.

Reprints and permissions information is available at https://horizonepublishing.com/journals/index.php/PST/open_access_policy

Publisher's Note: Horizon e-Publishing Group remains neutral with regard to jurisdictional claims in published maps and institutional affiliations.

To cite this article: Morajkar S, Hegde S. Biodiversity, richness and spatial distribution of extant Pteridophytes in Kudremukh National Park, Western Ghats, India. Plant Science Today. 2021;8(4):848-858. https://doi.org/10.14719/pst.2021.8.4.1057

Plant Science Today, published by Horizon e-Publishing Group, is covered by Scopus, Web of Science, BIOSIS Previews, Clarivate Analytics, etc. See https://horizonepublishing.com/journals/index.php/PST/indexing_abstracting 